(2) Open Access Full Text Article

\title{
Improvement in ocular cicatricial pemphigoid following treatment for porphyria cutanea tarda
}

This article was published in the following Dove Press journal:

Clinical Ophthalmology

19 October 2012

Number of times this article has been viewed

\section{R Marshall Ford \\ Yousuf M Khalifa}

David and Ilene Flaum Eye Institute, University of Rochester Medical Center, Rochester, NY, USA
Correspondence: R Marshall Ford David and llene Flaum Eye Institute, University of Rochester, 60I Elmwood Avenue, Box 659, Rochester,

NY 14642, USA

$\mathrm{Tel}+\mathrm{I} 5852758944$

Fax +I 5852760292

Email marshall_ford@urmc.rochester.edu
Abstract: A 64-year-old Caucasian male complaining of redness and tearing for 3 years in both eyes was referred for evaluation of cicatricial conjunctivitis. Ocular cicatricial pemphigoid was suspected and this diagnosis was confirmed through biopsy. The patient's condition showed moderate improvement following treatment with methotrexate and mycophenolate mofetil. The patient was later diagnosed with porphyria cutanea tarda and phlebotomy treatments were subsequently initiated. The patient's ocular symptoms improved further after he began receiving these phlebotomy treatments, and conventional treatment was discontinued. The authors hypothesize that circulating porphyrins activated by ultraviolet light could be the cause of the ocular cicatricial pemphigoid in this patient.

Keywords: cicatricial conjunctivitis, phlebotomy treatments, circulating porphyrins, ultraviolet light

\section{Introduction}

Ocular cicatricial pemphigoid (OCP) is an uncommon, chronic autoimmune disease that affects mucous membranes, particularly the conjunctiva. ${ }^{1}$ The disease typically results in chronic conjunctivitis and causes conjunctival and corneal scarring, which can result in limbal stem cell deficiency and blindness. ${ }^{2}$ Adequate control of ocular inflammation usually requires systemic as well as topical immunosuppressants. Commonly used systemic medications include prednisone, methotrexate, mycophenolate mofetil (MMF), and cyclophosphamide. ${ }^{3}$

The porphyrias are metabolic disorders caused by defective enzymes within the heme synthetic pathway. ${ }^{4}$ These defective enzymes cause an accumulation of intermediates from the heme synthetic pathway that results in various clinical manifestations. ${ }^{4,5}$ Porphyria cutanea tarda is the most common of the porphyrias and results from a deficiency in uroporphyrin decarboxylase, which is the fifth enzyme in the heme synthetic pathway. ${ }^{6}$ This deficiency results in the accumulation of porphyrins in the liver and plasma. On exposure to light with a wavelength near $400 \mathrm{~nm}$, the porphyrins enter an excited state that can lead to the damage of proteins, lipids, and basement membranes. ${ }^{6}$ This process results in blisters, fibrosis, and scarring of the skin in areas of the body exposed to sunlight. ${ }^{6}$

Park et $\mathrm{al}^{7}$ have reported a case of a 31-year-old with cicatricial conjunctivitis who was biopsy negative for OCP and was later diagnosed with porphyria cutanea tarda; in this case the patient's clinical symptoms significantly improved after initiating phlebotomy treatments. The present authors report a similar case, in which pathology 
and direct immunofluorescence confirmed a diagnosis of OCP and where the patient's clinical condition also improved significantly upon the diagnosis and treatment of porphyria cutanea tarda.

\section{Case report}

A 64-year-old Caucasian male complaining of redness and tearing for 3 years in both eyes was referred for evaluation of cicatricial conjunctivitis. He had been treated with tobramycin and dexamethasone ophthalmic ointment in both eyes as needed and doxycycline $100 \mathrm{mg}$ by mouth daily with no improvement in his symptoms. He denied any changes in his vision. His past medical history was significant for chronic obstructive pulmonary disease. His family and social history were unremarkable.

On examination, the patient appeared healthy. His corrected visual acuity was 20/20 in both eyes. On slit lamp examination the patient had subconjunctival fibrosis, symblepharon, forniceal foreshortening, and trichiasis in both eyes (Figure 1). Examination of the corneas revealed multiple punctate epithelial erosions. A Schirmer's test was performed without anesthesia, showing $22 \mathrm{~mm}$ of wetting in the right eye and $13 \mathrm{~mm}$ in the left after 5 minutes. The rest of the anterior and posterior segment examination was unremarkable.

OCP was suspected and a bulbar conjunctival biopsy was performed. Direct immunofluorescence studies of the conjunctival biopsy specimen revealed immunoglobulin G4 deposits in the basement membrane zone of the junctional area (Figure 2), consistent with OCP. Given the findings of subconjunctival fibrosis and symblepharon formation in both eyes, the patient was diagnosed with bilateral stage III pemphigoid. The patient was started on methotrexate $15 \mathrm{mg}$ by mouth weekly and prednisone $20 \mathrm{mg}$ by mouth daily.

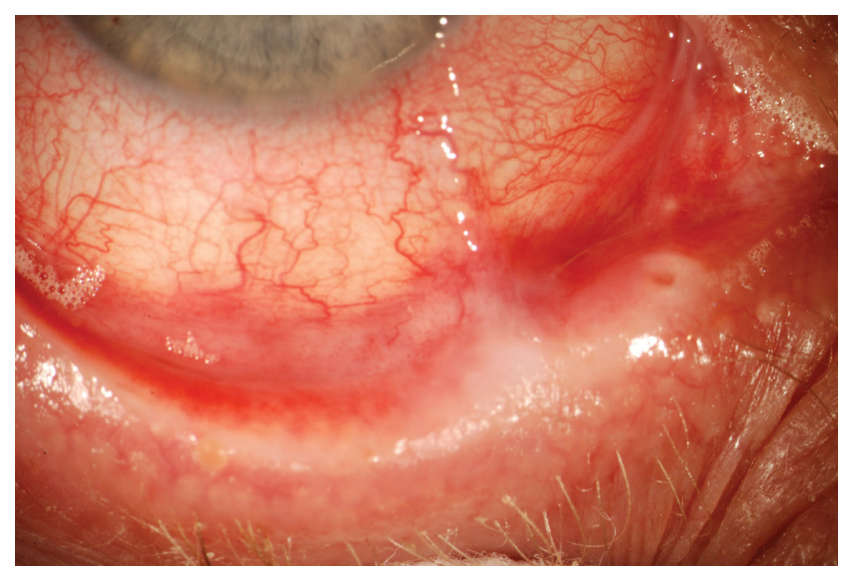

Figure I Initial slit lamp photograph showing subconjunctival fibrosis, symblepharon, and forniceal foreshortening.
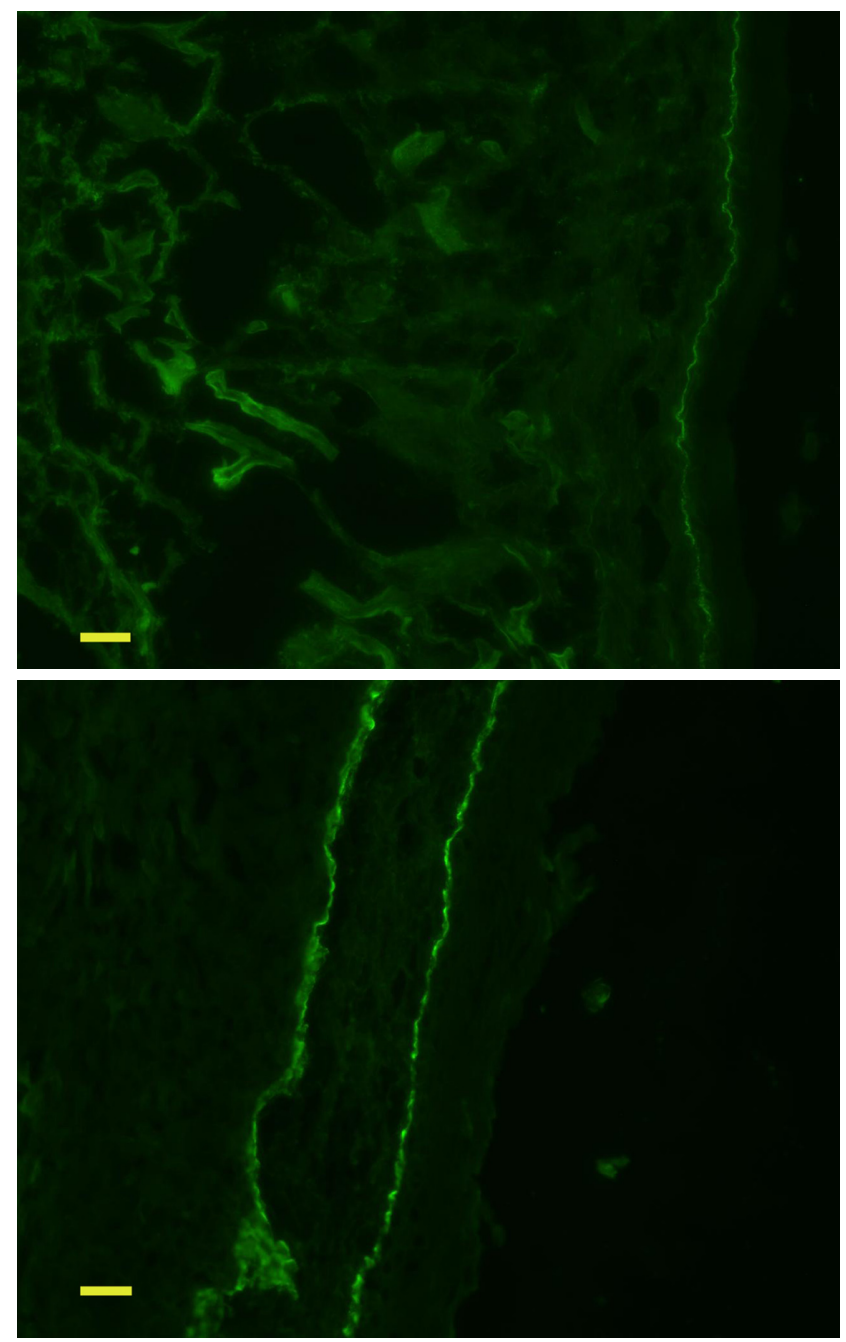

Figure 2 Digital photomicrographs of the conjunctival biopsy, showing immunoglobulin G4 deposits in the basement membrane zone.

Notes: Scale bar $5 \mu \mathrm{m}$; magnification 200x. Immunofluorescence slides courtesy of Beutner Laboratories, Buffalo, New York.

The patient demonstrated gradual improvement in the conjunctival inflammation after starting the methotrexate and prednisone. The patient was subsequently tapered off the prednisone, while the methotrexate $15 \mathrm{mg}$ by mouth weekly was continued. After 4 months of treatment with the methotrexate, the patient's conjunctival inflammation began to worsen and his regimen was subsequently changed from methotrexate to MMF $1000 \mathrm{mg}$ by mouth twice daily. Initial improvement in his subconjunctival injection was observed after starting the MMF.

Approximately 3 months after initiating MMF treatment, the patient was diagnosed with porphyria cutanea tarda. He was subsequently started on phlebotomy treatments and his conjunctival injection resolved. The patient's conjunctival inflammation appeared stable following initiation of the phlebotomy treatments and the MMF was 


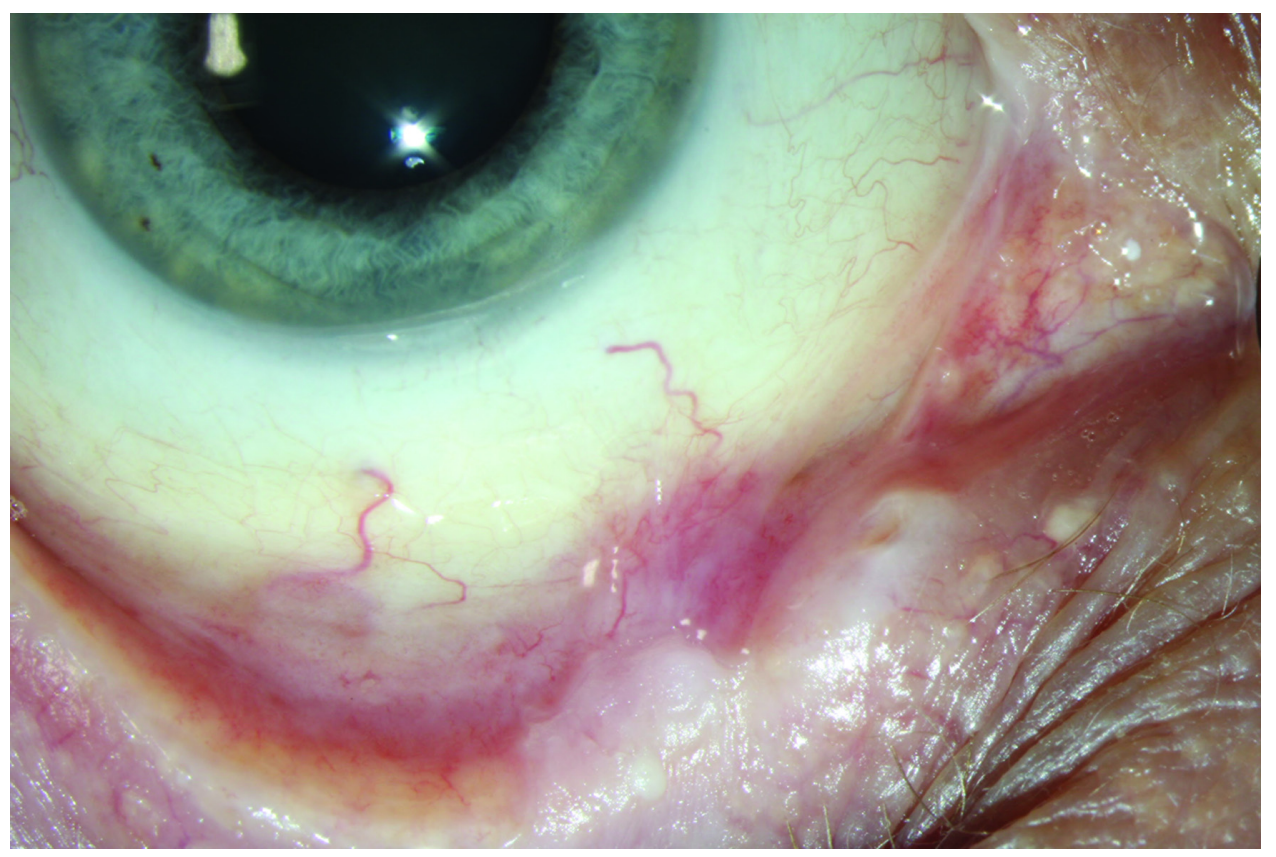

Figure 3 Slit lamp photograph taken 9 months after initiation of phlebotomy treatments, showing significantly reduced inflammation.

subsequently discontinued. Approximately 6 weeks following discontinuation of the MMF, the patient returned with mildly increased conjunctival injection and trichiasis in both eyes. Epilation was performed and the patient was started on 1\% prednisolone acetate (one drop in both eyes twice daily). The patient's conjunctival inflammation stabilized and he was tapered down to one drop of $1 \%$ prednisolone acetate in both eyes once daily. Since initiation of the phlebotomy treatments, the patient's conjunctival inflammation and subconjunctival fibrosis has remained quiescent for 4 months without requiring MMF (Figure 3).

\section{Discussion}

OCP is believed to be an autoimmune disease of genetic predisposition, and it is likely that a second-hit environmental trigger is required to initiate onset of the disease. ${ }^{1}$ It has been thought this could include chemical exposure or microbial environmental triggers. The present case suggests that the patient's porphyria could be a causal factor associated with the OCP and could even have been the environmental trigger that stimulated the disease to occur. The porphyrins are present in plasma and therefore they would be present in the ocular surface vasculature. ${ }^{5}$ The ocular surface is constantly exposed to light. Exposure to ultraviolet light would lead the porphyrins to enter into an excited state, resulting in inflammation and damage to the ocular surface - similar to the process that occurs in the skin. This process could be the trigger to either initiate or exacerbate OCP. In the present case, the patient's conjunctival inflammation was observed to significantly improve following initiation of treatment for his porphyria. A similar response was observed in the aforementioned case reported by Park et al, ${ }^{7}$ although that particular patient was biopsy negative for OCP and was positive for hepatitis $\mathrm{C}$ virus infection; in addition, the patient remained on methotrexate. The patient in the present case was unique in that he was biopsy positive for OCP and his clinical improvement was significant enough after starting phlebotomy treatments that his MMF was discontinued.

\section{Conclusion}

The authors consider that this case, as well as the case reported by Park et al, ${ }^{7}$ sheds new light on the search for the etiology of OCP and the subsequent treatment options for patients with this disease.

\section{Disclosure}

The authors report no conflicts of interest in this work.

\section{References}

1. Krachmer J, Mannis M, Holland E. In: Krachmer J, Mannis M, Holland E, editors. Cornea. 3rd ed. China: Mosby; 2011:591-597.

2. Ahmed M, Zein G, Khawaja F, Foster CS. Ocular cicatricial pemphigoid: pathogenesis, diagnosis and treatment. Prog Retin Eye Res. 2004;23(6): 579-592.

3. Galdos M, Etxebarría J. Intravenous immunoglobulin therapy for refractory ocular cicatricial pemphigoid: case report. Cornea. 2008;27(8): 967-969.

4. Meyer UA. Porphyria. In: Braunwald E, Isselbacher KJ, Petersdorf RG, Wilson JD, Martin JB, Fauci AS, editors. Harrison's Principles of Internal Medicine. 13th ed. New York: McGraw-Hill; 1994:2073-2079. 
5. Anderson KE. Porphyrias: an overview. UpToDate 19.2 [clinical decision support system on the Internet]. 2011 [updated February 23, 2012]. http://www.uptodate.com/contents/porphyrias-an-overview. Accessed November 15, 2011.

6. Singal AK, Anderson KE. Porphyria cutanea tarda and hepatoerythropoietic porphyria. UpToDate 19.2 [clinical decision support system on the Internet]. 2011 [updated June 14, 2012]. http://www.uptodate.com/ contents/porphyria-cutanea-tarda-and-hepatoerythropoietic-porphyria. Accessed November 15, 2011.
7. Park AJ, Webster GF, Penne RB, Raber IM. Porphyria cutanea tarda presenting as cicatricial conjunctivitis. Am J Ophthalmol. 2002;134(4): 619-621.

\section{Publish your work in this journal}

Clinical Ophthalmology is an international, peer-reviewed journal covering all subspecialties within ophthalmology. Key topics include: Optometry; Visual science; Pharmacology and drug therapy in eye diseases; Basic Sciences; Primary and Secondary eye care; Patient Safety and Quality of Care Improvements. This journal is indexed on

\section{Dovepress}

PubMed Central and CAS, and is the official journal of The Society of Clinical Ophthalmology (SCO). The manuscript management system is completely online and includes a very quick and fair peer-review system, which is all easy to use. Visit http://www.dovepress.com/ testimonials.php to read real quotes from published authors. 